\title{
MECHANICAL PROPERTIES AND WATER-ABSORPTION CHARACTERISTICS OF SELECTED NATURAL FIBERS AS A REPLACEMENT FOR ASBESTOS
}

\author{
MEHANSKE LASTNOSTI IN ABSORBCIJA VODE IZBRANIH \\ NARAVNIH VLAKEN KOT ZAMENJAVA ZA AZBEST
}

\begin{abstract}
Anuoluwapo Samuel Taiwo', Emmanuel Oseremen Egbodion'1, Adeolu Adesoji Adediran²*, Samuel Akinyemi Shittu ${ }^{1}$, Samuel Olufemi Balogun ${ }^{3}$, Olanrewaju Seun Adesina ${ }^{2}$
\end{abstract}

\begin{abstract}
${ }^{1}$ Department of Metallurgical and Materials Engineering, Federal University of Technology, Akure, PMB 704, Ondo State, Nigeria 2Department of Mechanical Engineering, College of Engineering, Landmark University, PMB 1001, Omu-Aran, Kwara State, Nigeria ${ }^{3}$ Department of Science Laboratory Technology, Ogun State Institute of Technology, Igbesa PMB 2005, Igbesa, Ogun State, Nigeria
\end{abstract}

Prejem rokopisa - received: 2020-06-22; sprejem za objavo - accepted for publication: 2020-09-17

This work investigates the influence of banana (Musa Sapientum) and jute fibers as a reinforcement in a cement/waste brown paper pulp matrix for applications in housing construction in Nigeria. The natural fibers were extracted from banana trunk and cocoa sack and, thereafter, treated with 1-M sodium hydroxide $(\mathrm{NaOH})$ for $2 \mathrm{~h}$ to expose the lignin and cellulose and thus expose the hemicellulose content of the fibers. The treated fibers were allowed to dry in air for 7 days before cutting into short fibers of $10 \mathrm{~mm}$ length. Paper pulp was prepared by soaking waste brown cardboard papers in water for $24 \mathrm{~h}$, thereafter, it was grinded in the paper pulp machine to form a paper pulp slurry, and then sun-dried for 5 days. The treated fibers were thoroughly mixed with the dried paper pulp to develop Fiber Cement Board (FCB) samples of varied weight content $(5,10,15$, and 20) $w / \%$ using the hand lay-up technique with the aid of a cold compacting machine. Thereafter, an appropriate quantity of cement as binder and treated sugarcane bagasse as filler material were added to the mix. The developed FCB samples were allowed to cure in air in the laboratory for 28 days before testing. Flexural, compressive, thermal conductivity, and water absorption tests were carried out on the samples using a universal testing machine, Lee's disk apparatus, and the percentage weight of different immersed samples in water, respectively. The results of the mechanical properties examined showed that FCB sample D containing ( $10 \mathrm{w} / \%$ banana fiber, $10 \mathrm{w} / \%$ jute fiber, $15 \mathrm{w} / \%$ cement/bagasse and $65 \mathrm{w} / \%$ paper pulp) gave the optimum results for the flexural and compressive properties with a respective value of $0.843 \mathrm{MPa}$ and $7.333 \mathrm{MPa}$, while FCB sample F gave the best results for the thermal conductivity and water-absorption property.

Keywords: natural fibers, waste papers/cement matrix, mechanical properties, Housing construction

V članku avtorji opisujejo raziskavo izdelave kompozitnega materiala, uporabnega za hišne konstrukcije v Nigeriji. Material so izdelali iz vlaken bananovca (Musa Sapientum) in jute kot ojačitev za kašnato matrico iz cementa in odpadnega rjavega papirja. Naravna vlakna so pridobili iz debel bananovca in jute iz vreč za kakav. Sledila je njihova dveurna obdelava v $1 \mathrm{M}$ natrijevem hidroksidu $(\mathrm{NaOH})$ za sprostitev lignina in celuloze. Na ta način so iz vlaken izločili lignin in hemicelulozo. Obdelana vlakna so sušili sedem dni na zraku in jih nato razrezali na kratka vlakna dolžine $10 \mathrm{~mm}$. Papirnato kašo so pripravili s 24-urnim namakanjem rjavega kartonskega papirja v vodi. Sledilo je drobljenje v stroju za izdelavo papirnate kaše . Nastala je gošča, ki so jo pet dni ponovno sušili na soncu. Obdelana vlakna so dobro premešali s posušeno papirnato pulpo $(5,10,15$ in 20$) w / \%$ in kot vezivo dodali primerno količino $(15$ mas. \%) cementa in obdelani trsni sladkor. Iz te mase so izdelali preizkušance; to je cementne plošče, ojačane z naravnimi vlakni. Pred testiranjem so vzorce sušili na zraku v laboratoriju še 28 dni. Na univerzalnem preizkuševalnem stroju so nato določili upogibno in tlačno trdnost vzorcev. Poleg tega so določili še njihovo toplotno prevodnost z Leejevim preizkuševalnim aparatom in absorpcijo vode. Vzorci označeni s črko D, ki so vsebovali 10 mas. \% vlaken bananovca, $10 \mathrm{w} / \%$ vlaken jute, $15 \mathrm{w} / \%$ cementa/sladkorja in $65 \mathrm{w} / \%$ papirne pulpe so imeli optimalno upogibno $(0,843 \mathrm{MPa})$ oziroma tlačno trdnost $(7,333 \mathrm{MPa})$, medtem ko so imeli vzorci $\mathrm{F}$ najmanjšo toplotno prevodnost in absorpcijo vode.

Ključne besede: naravna vlakna, matrica iz odpadnega papirja in cementa, mehanske lastnosti, konstrukcija ostrešja

\section{INTRODUCTION}

The increasing interest in the application of natural fibers in the area of composite materials development is undisputable. This is primarily due to sustainability, as well as their appreciable mechanical properties and low cost. ${ }^{1-3}$ The changes perceived amongst diverse natural fibers are owing to their climatic conditions, chemical composition and origin. ${ }^{4}$ Normally, plant fibers are composed of $10-20 \%$ of hemicellulose, $5-15 \%$ of lignin,

*Corresponding author's e-mail:

adediran.adeolu@1mu.edu.ng (Adediran Adeolu)
$60-70 \%$ of cellulose and approximately $2 \%$ of pectin and waxes. ${ }^{1}$ Banana fiber is gotten from the overlaid leaves forming the quasi-trunk of the plant, which presently has not been put to any significant use in Nigeria, except for a very low fraction devoted to livestock feeding, which is less than $2 \%$ of the total produce of banana fibers in the country. It, however, falls into the Musa species, as a monocotyledonous plant. Banana is one of the most significant crops planted in Sahara Africa, ${ }^{5}$ which made it the most important producers of banana in Africa. It is imperative to point out here that fibers are obtained from the quasi-trunks of the plant after the fruit 
has been garnered, moreover, each plant bears fruit only once in its entire life cycle. This is one of the key benefits of banana fibers in contrast with other natural fibers, as this one is gotten from an agricultural waste. ${ }^{6}$ Jute fiber on the other hand, is extracted from cocoa sack by unweaving the knitted cocoa sack to obtain long strands of jute fiber. ${ }^{7}$ Authors $^{3}$ investigated the changes occurring in jute fibers after $5 \% \mathrm{NaOH}$ solution treatment for different periods of $(0,2,4,6$, and 8$) \mathrm{h}$. A $9.63 \%$ weight loss was measured during $2 \mathrm{~h}$ of the treatment with a drop of hemicellulose content from $22 \%$ to $12.90 \%$. The tenacity and modulus of the treated fibers improved by $45 \%$ and $79 \%$, respectively, and the breaking strain was reduced by $23 \%$ after $8 \mathrm{hr}$ of treatment. The crystallinity of the fibers increased only after $6 \mathrm{hr}$ of treatment. It was also reported that the impact fatigue behaviour of vinylester matrix composites reinforced with untreated and alkali-treated jute fibers showed that a longer duration of the alkali treatment increased the crystallinity and gave a better fiber dispersion due to the removal of hemicellulose, while the alkalization for $4 \mathrm{~h}$ was the optimum treatment time to improve the interfacial bonding and fiber strength. Furthermore, the flexural strength of the alkali-treated jute fiber composites was higher than that of untreated jute fiber composites..$^{5,7}$ The practice of using natural fibers in the strengthening of polymeric parts has been extensively studied, particularly focusing on injection-molding technology. It is reported that an approximate 21,000 tons of natural fibers were used in European industry in 2003. ${ }^{1}$ In another report, the essential fibers for the industrial manufacturing of polymeric composites are sisal, hemp and flax fibers. ${ }^{1,5}$

Furthermore, research has shown that natural fibers have little or no detrimental effect on the environment, humans, and machinery, thus being considered as a close substitute for asbestos and glass fiber. ${ }^{8}$ Some research has also been carried out to understand the compression molding technique, with a view to strengthening its usage in natural-fiber-reinforced composite development, some with elongated fibers and others with entwined fibers, both for thermoplastic and thermosetting polymers. These studies revealed that certain mechanical properties of natural-fiber-reinforced composites were comparable with those reinforced with glass fiber, though the mechanical properties under moist conditions demonstrate a significant decrease in the natural fiber composites, due to their nature being hydrophilic or moisture absorbent. ${ }^{6}$ However, it has been established that the mechanical properties of composites strongly hinge on the alignment of the fibers, resulting in enhanced properties when the fiber is knitted and positioned in the composite in a proper orientation. Interestingly, several researches have been done on the manufacturing of natural-fiber-reinforced composite materials using fibers such as jute, hemp, and flax in knitted and un-knitted forms; however, little or no research has been found to report the use of banana fibers to develop composite materials. Furthermore, only a few researches have reported the use of banana fibers to produce yarns for technical textile products. ${ }^{1}$ Banana fibers consist of $11 \%$ lignin, $14 \%$ hemicellulose, $43.6 \%$ cellulose and other substances (such as pectin and waxes) making up the remaining $31.4 \% .4,7$ Chemical methods for fiber extraction are commonly performed with $\mathrm{NaOH}$, although other chemicals (such as stearic acid, benzoyl chloride, $\mathrm{KMnO}_{4}$ among others) can also be used., ${ }^{7,9}$ These processes may however, result in ecological problems as a result of the need to treat the remains produced. The mechanical methods are not capable of eliminating the lignin (non-cellulosic constituents). An alternative method is the use of organic processes, such as the immersed ${ }^{10}$ or solid-state ${ }^{11}$ fermentations. Enzymatic approaches are considered to be more ecologically friendly and circumvent the fibers' fracture, while altering the properties of the cellulosic fibers. ${ }^{12}$ Consequently, certain factors might influence the choice of enzymes, this includes: lignin content, composition, type of substrate, size, etc. ${ }^{12}$ Previous studies revealed that pectinase ${ }^{13}$ and xylanase ${ }^{14}$ are the most appropriate enzymes for fiber extraction. However, enzymatic approaches have been applied to pineapple, flax or hemp for fiber treatment. Celluloses are applied to eliminate fibrils from the surfaces of the fibers and improve the surface smoothness of the fiber. ${ }^{15}$ Moreover, this treatment might also destroy the fibers and weaken their mechanical properties. ${ }^{15}$ The present study investigates the influence of banana (Musa Sapientum) and jute fibers as reinforcement in cement/waste brown paper pulp matrix with potential applications in housing construction (particularly intended for areas such as internal roofing/ceiling and partitioning) in Nigeria.

\section{EXPERIMENTAL PART}

\subsection{Materials}

The banana and jute fibers used in this present study were gotten from the stem of a plant obtained at Apatapiti layout, FUTA south gate, Akure, Ondo State, Nigeria, and cocoa sack obtained from Oja Oba market in Akure, Ondo State, Nigeria. The agricultural waste (sugarcane bagasse) was obtained locally from already sucked sugar cane, The Portland cement matrix used in the study was gotten from Apatapiti layout, FUTA south gate, Akure, Ondo State, Nigeria. The reagent sodium hydroxide $(\mathrm{NaOH})$ used for the treatment of the fibers was obtained from Pascal's Scientific Limited, Akure, Ondo State. The distilled water used in this work, was obtained from the Department of Chemistry, Federal University of Technology, Akure, Nigeria. 


\subsection{Methods}

\subsubsection{Extraction of fibers}

Banana fibers were extracted manually from the quasi-trunk of the plant after the fruit has been harvested; thereafter, the quasi-trunk of the plant was subjected to water retting process by soaking it in distilled water, which allowed the swelling of the trunk and loosening of the strands of the fiber. The loosened strands were extracted manually from the water-retting process and then sun-dried for 3 days, as shown in Figures $\mathbf{1 a}$ and $\mathbf{1 b}$, prior to chemical treatment using $\mathrm{NaOH}$ solution. Jute fibers were extracted from cocoa sack by unweaving the knitted cocoa sack to obtain long strands of jute fiber, as shown in Figure 2b, before the chemical treatment with $\mathrm{NaOH}$ solution.

\subsubsection{Preparation of paper pulp}

Paper pulp was prepared by first soaking waste brown carton paper in water for $24 \mathrm{~h}$ in order to soften it and make it easy for the fibers to separate from each other and also to reduce the grinding time; this was in agreement with previous work. ${ }^{16}$ Thereafter, the soaked paper was charged into the paper pulping machine and allowed to grind for about 10-15 minutes to obtain paper pulp slurry, which was then sun dried for 5 days before using it to develop the fiber cement boards.

\subsubsection{Treatment of fibers with 1-M NaOH}

The extracted banana and jute fibers were treated separately with 1-M NaOH solution, which was prepared in the laboratory by weighing $40 \mathrm{~g}$ of $\mathrm{NaOH}$ pellet into
$1000 \mathrm{ml}$ of distilled water. The treatment was done at room temperature for $2 \mathrm{~h}$ to expose the soluble lignin and cellulose and attack the hemicellulose content from the surface of the fibers. In this way, the interfacial bonding strength between the fibers and the matrix is improved. ${ }^{6}$ The treated fibers were allowed to dry in air at room temperature for 7 days before cutting into short fibers of $10 \mathrm{~mm}$ to give room for good adhesion of the fibers with other constituent materials, which was used for the development of the fiber cement boards.

\subsubsection{Production of fiber cement boards or composite samples}

Natural-fiber-reinforced composite samples were developed using the compression-molding technique. A predetermined proportion of fibers, paper pulp, and cement matrix was mixed vigorously in a plastic mold in other to obtain a homogeneous mixture due to the different proportions. The production was carried out at room temperature. The mixed proportion was poured into compression, flexural, and thermal conductivity molds. The filled mold was then placed in between the lower and the upper plates of the cold-compression machine at room temperature for 2 min under an applied pressure of $0.2 \mathrm{kPa}$. In this way, composite samples filled with varying weight fractions of natural fibers $(5,10,15$, and 20) $w / \%$ were produced while using teflon sheet to cover the top and bottom part of the mold for easy release after molding. Figures $\mathbf{2 a}$ to $\mathbf{2 b}$ shows the composite samples produced for flexural and thermal conductivity tests respectively.
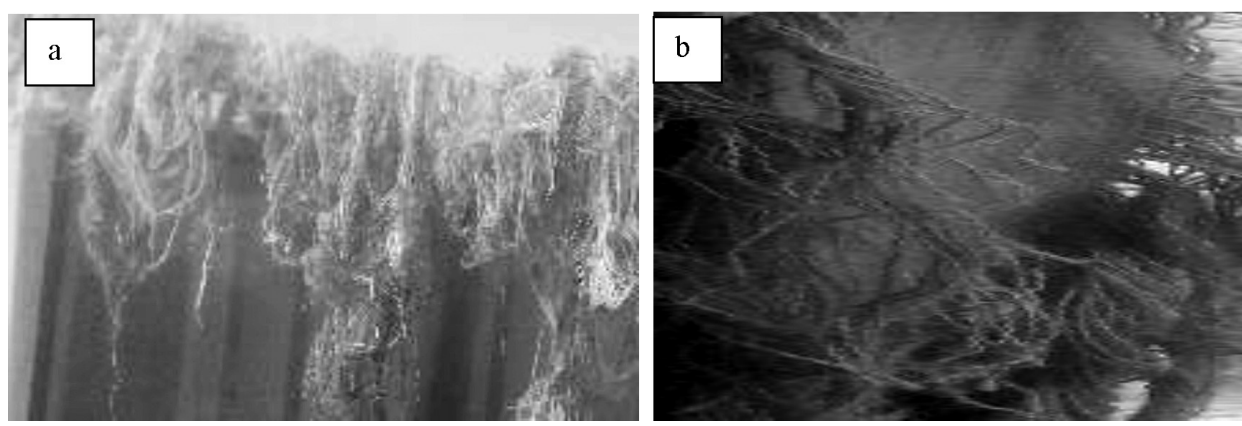

Figure 1: Showing a) sun dried strands of banana fiber, b) strands of jute fibers unwoven from cocoa sack
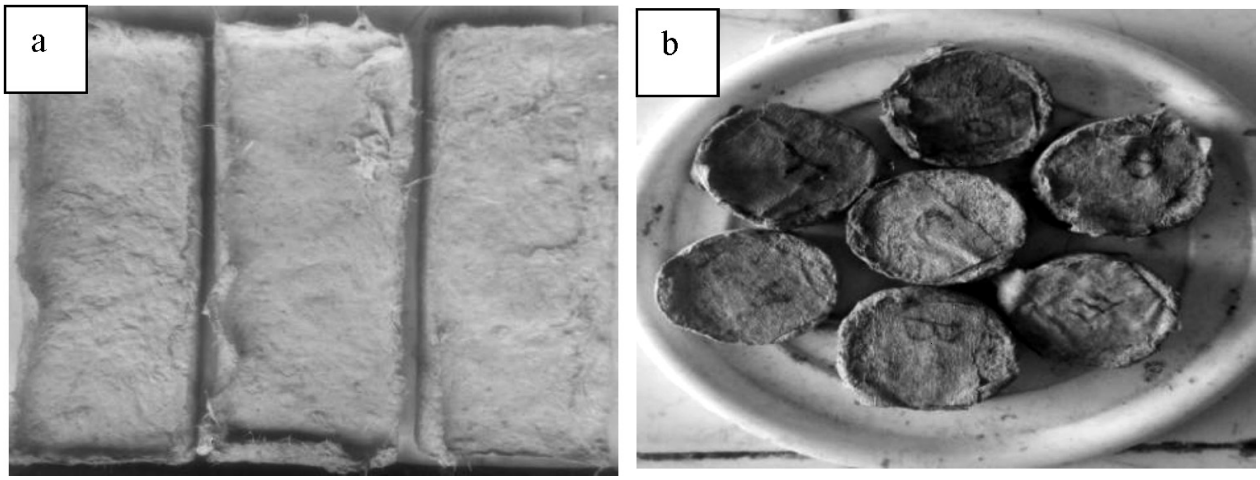

Figure 2: Showing a) flexural samples, b) thermal conductivity samples 
Table 1: Composition/percentage weight for composite samples (flexural, compressive, and thermal conductivity)

\begin{tabular}{|c|c|c|c|}
\hline $\begin{array}{c}\text { Sample } \\
\text { designation }\end{array}$ & $\begin{array}{c}\text { Matrix } \\
\text { (paper pulp) } \\
w / \%\end{array}$ & $\begin{array}{c}\text { Reinforcement } \\
\text { (jute/banana) } \\
w / \%\end{array}$ & $\begin{array}{c}\text { Binder } \\
\text { (cement) } \\
w / \%\end{array}$ \\
\hline Control (O) & 100 & - & - \\
\hline $\mathrm{A}$ & 85 & - & 15 \\
\hline $\mathrm{B}$ & 65 & $20 /-$ & 15 \\
\hline $\mathrm{C}$ & 65 & $15 / 5$ & 15 \\
\hline $\mathrm{D}$ & 65 & $10 / 10$ & 15 \\
\hline $\mathrm{E}$ & 65 & $5 / 15$ & 15 \\
\hline $\mathrm{F}$ & 65 & $-/ 20$ & 15 \\
\hline
\end{tabular}

\subsection{Characterization and water-absorption properties}

The various mechanical tests carried out on the developed composite samples are as follows:

\subsubsection{Compressive test}

A compressive test is generally carried out on cylindrical samples to determine the compressive modulus, compressive strength at peak, and compressive strength at the break of the samples were determined using an Instron 5966 tester with a load cell of $10 \mathrm{kN}$ in accordance with the standard. ${ }^{17}$

\subsubsection{Flexural test}

The flexural strength of the composite was evaluated by performing flexural three-point bending test on the composite. The test was performed at room temperature using Testometric Universal testing Machine operated at a crosshead speed of $3.0 \mathrm{~mm} / \mathrm{min}$. The test procedure and the flexural strength determination were performed in accordance with the standard. ${ }^{18}$

\subsubsection{Thermal conductivity}

Thermal conductivity is the measure of the heat passed through a material at a given temperature. The thermal conductivity was determined using Lee's disk apparatus. ${ }^{19}$ The time at each temperature interval is recorded and used in calculating the value of $\mathrm{k}$ using Equation (1).

$$
k=\frac{m c_{\mathrm{p}} d(\partial T / \partial t)}{A\left(T_{1}-T_{2}\right)}
$$

where $K$ is the thermal conductivity $(\mathrm{W} / \mathrm{mK}), m$ is the mass of the disk $(\mathrm{kg})$, and $C_{\mathrm{p}}$ is the specific heat capacity of the metal $(\mathrm{kJ} / \mathrm{kgK})$ as presented in Equation (2):

$$
\partial T=\left(T_{1}-T_{2}\right)(\mathrm{K})
$$

$A$ is the area $\left(\mathrm{m}^{2}\right)$ and $t$ is the time (s).

\subsubsection{Water-absorption test}

The water-absorption test for the developed composite samples was carried out in accordance with ASTM D570-10, a standard test method for the water absorption of plastics. ${ }^{20}$ Composite samples were weighed and immersed in distilled water at room temperature. The weight of the samples prior to immersion was taken as
$\mathrm{W}_{1}$. The samples were then taken out and weighed at 24 $\mathrm{h}$ intervals for up to 5 days. This was after water saturation in all the samples had been observed. The samples were weighed immediately after wiping out the water on the sample surface. The readings were taken with a digital weighing balance and the weight of the samples after immersion was taken as $\mathrm{W}_{2}$. The percentage water absorption was calculated using Equation (3). ${ }^{6}$

$$
W_{A}(\%)=\frac{\left(W_{2}-W_{1}\right)}{W_{1}} \times 100
$$

Where $W_{1}$ is the initial weight of the sample prior to immersion $(\mathrm{g}), W_{2}$ is the weight of the sample after $24 \mathrm{~h}$ of immersion $(\mathrm{g}), W_{\mathrm{A}}$ is the percentage of absorption.

From Equation (3), the graphs of weight gain vs. immersion time, percentage water absorption vs. immersion time were plotted.

\section{RESULTS}

The representative variations of the flexural properties are as shown in Figures 3 to $\mathbf{5}$, respectively. The flexural modulus is presented in Figure 6, while Figures $\mathbf{7}$ and $\mathbf{8}$ show the compressive properties. The variation in the composites compressive moduli are as shown in Figure 9. The thermal property variations are in Figures 10 to 13 , showing the variation in the weight gained, the percentage of water absorption and the SEM images for samples A and D, respectively.

Table 2: Weight gained and immersion time of the composite samples for the water-absorption test

\begin{tabular}{|c|c|c|c|c|c|}
\hline & \multicolumn{5}{|c|}{ Immersion time (h)/weight gained } \\
\hline $\begin{array}{c}\text { Samples } \\
\text { designation }\end{array}$ & $24 \mathrm{~h}$ & $48 \mathrm{~h}$ & $72 \mathrm{~h}$ & $96 \mathrm{~h}$ & $120 \mathrm{~h}$ \\
\hline $\mathrm{O}$ & 1.646 & 1.761 & 1.779 & 1.785 & 2.062 \\
\hline $\mathrm{A}$ & 1.423 & 1.501 & 1.557 & 1.558 & 1.629 \\
\hline $\mathrm{B}$ & 1.649 & 1.721 & 1.782 & 1.799 & 1.963 \\
\hline $\mathrm{C}$ & 1.499 & 1.596 & 1.625 & 1.664 & 1.665 \\
\hline $\mathrm{D}$ & 1.485 & 1.649 & 1.705 & 1.753 & 1.799 \\
\hline $\mathrm{E}$ & 1.461 & 1.617 & 1.663 & 1.677 & 1.777 \\
\hline $\mathrm{F}$ & 1.213 & 1.311 & 1.375 & 1.378 & 1.466 \\
\hline
\end{tabular}

\section{DISCUSSION}

Figure 3 shows the variation of the flexural strength at the peak with the composite samples. It was observed that all the composites samples with fiber reinforcement showed a better flexural strength at the peak than the control sample 'O', which has no fiber addition. This demonstrates that the addition of the selected natural fibers contributed to the improved flexural strength at the peak of the composite samples. However, the optimum flexural strength at the peak was observed in the FCB sample 'D' with $10 / 10 w / \%$ of jute/banana (JB) fibers with a value of $0.84343 \mathrm{MPa}$. This can be attributed to the equivalent percentages of fiber addition and the dis- 


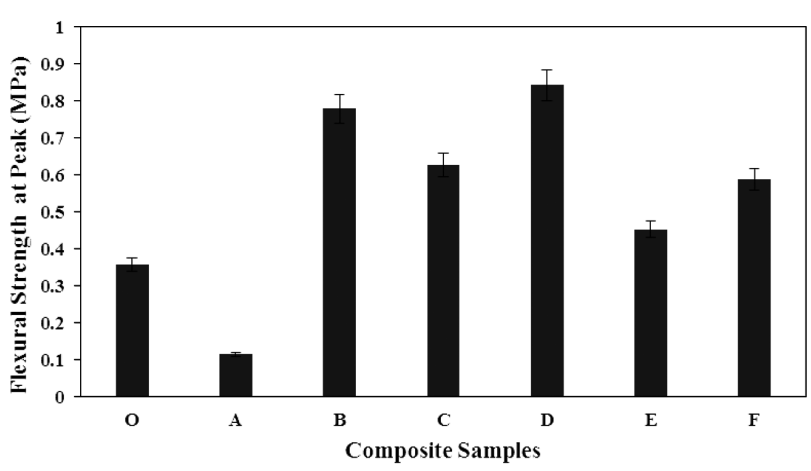

Figure 3: Variation of the flexural strength at the peak with the composite samples

tribution between the JB fibers within the paper pulp/cement matrix. Furthermore, the FCB sample 'B' with a single reinforcement of 20/0 $w / \%$ JB fibers content with a value of $0.77946 \mathrm{MPa}$; tend to give a better result when compared with sample $\mathrm{F}$ having a single reinforcement of $0 / 20 w / \%$ JB fibers. This suggests that jute fiber was more responsible for the improved strength in the composite. Although a gradual increase in the percentage of banana fiber resulted in an increase of the flexural strength at the peak of the composite sample, as observed in sample D. This trend, however, agrees with previous findings, ${ }^{21}$ which reported that the flexural strength of composites could increase with a gradual increase in the percentage of reinforcement. Figure 4 shows the variation of flexural strength at the break with composite samples. It was also observed that all the composites samples with fiber reinforcement had better flexural strength at the break, compared to the control sample 'O', which had no fiber addition. It is evident that the addition of the selected natural fibers has contributed to the improved strength of the composite samples. Moreover, the optimum flexural strength at the break was observed in the FCB sample 'D' with $10 / 10$ w/\% of JB fibers with a value of $0.7473 \mathrm{MPa}$. This may be attributed to the equal percentages of fiber addition and distribution between the jute/banana fibers within the paper pulp/cement matrix. A similar trend was observed for composite samples with individual fiber reinforcement evident in FCB sample B, and F with $20 / 0$ and $0 / 20$ w/\%

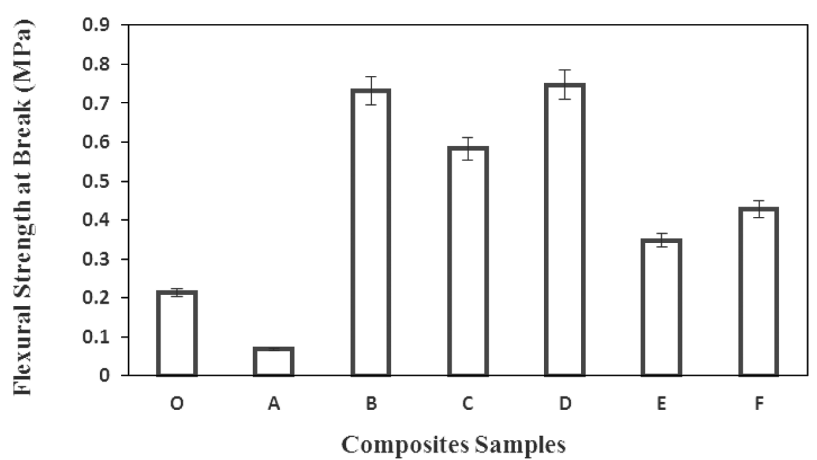

Figure 4: Flexural strength at the breaking point of the composite samples

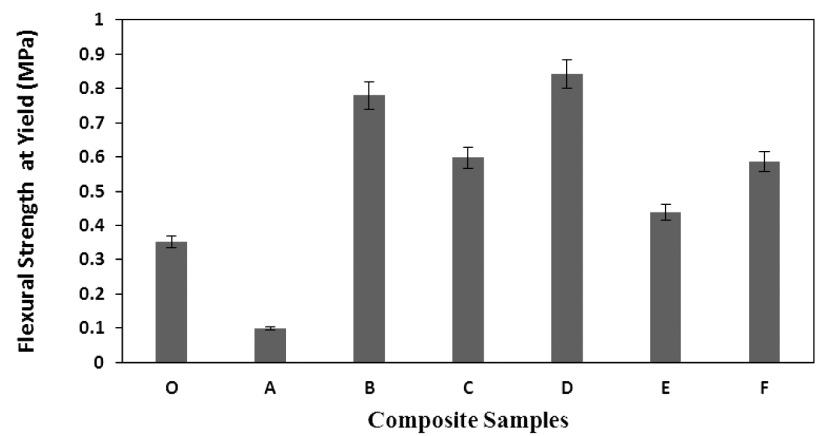

Figure 5: Flexural strength at the yield point of the composite samples

of JB fibers content with a value of $0.73623 \mathrm{MPa}$ and $0.42723 \mathrm{MPa}$, respectively. However, sample 'E' with $5 / 15 w / \%$ of JB fibers content gave the minimum flexural strength at break with a value of $0.34676 \mathrm{MPa}$. This can be attributed to the lower percentage of jute fiber in the composite sample, which resulted in the poor flexural strength at the break property. Figure 5 shows the variation in flexural strength at yield with composite samples. A similar trend was observed for all the collections of FCB samples. It was noted that the flexural strength at yield was optimum in sample 'D', which has 10/10 w/\% of JB fibers as reinforcement content with a value of $0.84343 \mathrm{MPa}$. This was followed by FCB sample 'B' with $20 / 0 w / \%$ of JB fibers content with a value of $0.77946 \mathrm{MPa}$. However, the composite sample 'E' with $5 / 15 w / \%$ of JB fibers content gave the least result with a value of $0.43855 \mathrm{MPa}$.

From the result in Figure 6, it was observed that the FCB composite sample 'D' with $10 / 10 w / \%$ of JB fibers showed the best flexural modulus with a value of 0.029 $\mathrm{MPa}$. This gave a very high stiffness and rigidity when compared to the control sample ' $\mathrm{O}$ ' with a value of 0.02 $\mathrm{MPa}$. Afterwards, there seems to be a linear decrease in the flexural modulus of the FCB composite samples as the percentage of jute fiber reduces. This showed that the treated banana fiber can be abruptly responsible for the enhanced flexural modulus of the composite samples. The seeming drop in the flexural modulus showed by samples 'B' and ' $\mathrm{C}$ ' may be due to a factor such as fiber pulling. Fiber pulling occurs occasionally as a result of experimental imperfections that reduce the fiber distribution and/or dispersion. Since good fiber distribution has been known to promote good interfacial bonding, and re-

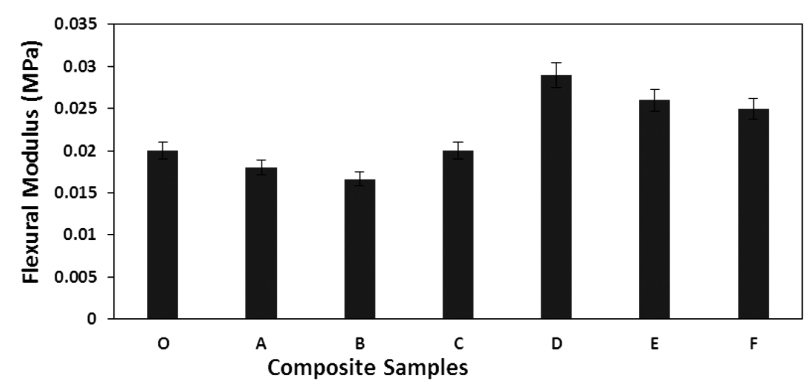

Figure 6: Flexural modulus of the composite samples 


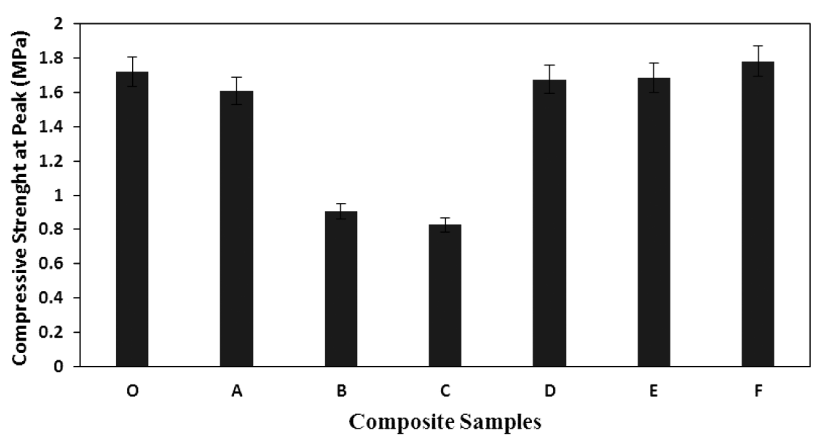

Figure 7: Variation of the compressive strength at the peak with the composite samples

duce voids by ensuring that filler agglomerate is fully surrounded by the matrix, thereby giving room for the improved flexural modulus. The variations in the compressive strength at peak for the developed FCB composite samples is as presented in Figure 7. It is evident from the chart that a gradual increment in the compressive strength at the peak of the composite sample was observed from $10 / 10 w / \%, 5 / 15 w / \%$ and $0 / 20 w / \%$. The JB fibers content had a compressive strength value of (1.6756; 1.6877 and 1.7836) MPa, respectively. Furthermore, it was observed that the composite sample ' $\mathrm{F}$ ' which has $0 / 20 w / \%$ JB fibers had the optimum result for the compressive strength at the peak with a value of $1.7836 \mathrm{MPa}$. This might be attributed to the higher percentage of treated banana fiber that was responsible for the optimum result in the composite sample. Figure 8 shows the variation in compressive strength at break with composite samples. It is inferred that the composite samples D, E, and F with fiber reinforcement had a better compressive strength at the break compared to the control sample 'O', which had no fiber addition. This shows that the addition of the selected natural fibers contributed to the improved strength of the composite samples. It was observed that an optimum compressive strength at the break was recorded in the FCB sample 'D' with 10/10 $w / \%$ of JB fibers with a value of $2.102 \mathrm{MPa}$. This can also be attributed to the equivalent percentages of fibers addition and distribution between jute/banana fibers within the paper pulp/cement matrix. This was followed

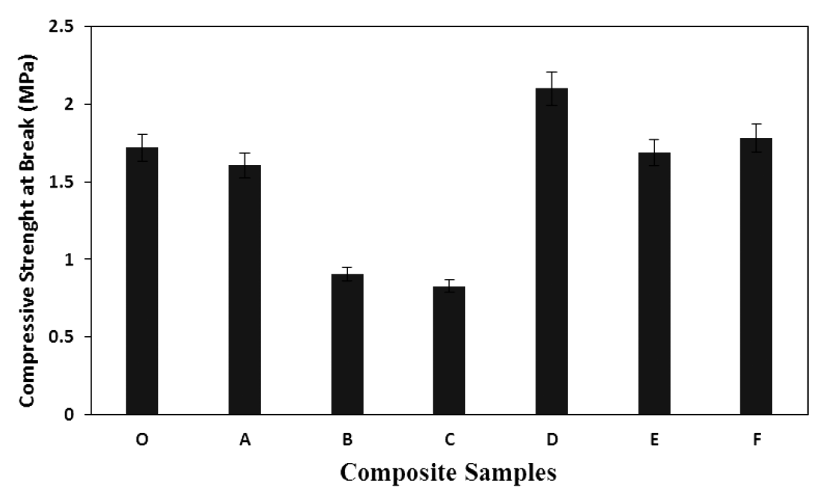

Figure 8: Variation of the compressive strength at the breaking point with the composite samples

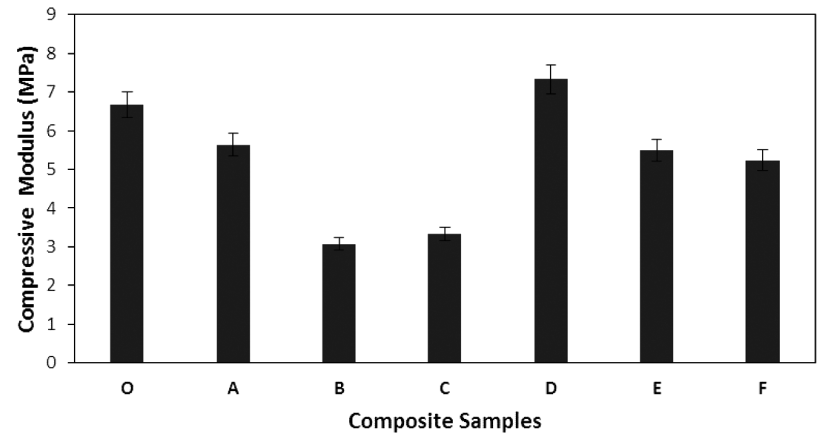

Figure 9: Variation of the compressive modulus with the composite samples

by FCB sample 'F' with $0 / 20 w / \%$ of JB fibers content with a value of $1.7836 \mathrm{MPa}$. However, sample 'C' with $15 / 5 w / \%$ of JB fibers content gave the minimum compressive strength at the break with a value of 0.8276 $\mathrm{MPa}$. This can be due to the lower percentage of banana fiber in the composite sample, which resulted in the poor compressive strength at the break.

From the result in Figure 9, it was also observed that the FCB composite sample 'D' with $10 / 10 w / \%$ of JB fibers showed the best compressive modulus with a value of 7.333 MPa. This showed a very high stiffness and rigidity value when compared with the control sample 'O', with a value of $6.667 \mathrm{MPa}$. However, there appeared to be a linear decrease in the compressive modulus of the FCB composite samples as the percentage of jute fiber reduces. It is inferred that the treated banana fiber was abruptly responsible for the enhanced compressive modulus of the composite samples. Thermal conductivity is a measure of the ability of a material to conduct heat. Heat transfer occurs at a lower rate in materials of low thermal conductivity than in materials of high thermal conductivity. The thermal conductivity of the material can depend on the temperature. The thermal conductivity of the developed FCB composite samples is shown in Figure 10.

A representative plot showing the thermal conductivity of composites samples is as presented in Figure 10. It is revealed that the composite samples with individual fiber addition; i.e., samples 'B' and 'F', gave a respective value of $0.129 \mathrm{~W} / \mathrm{mK}$ and $0.111 \mathrm{~W} / \mathrm{mK}$. These appeared to be the optimum results; an indication that there seems

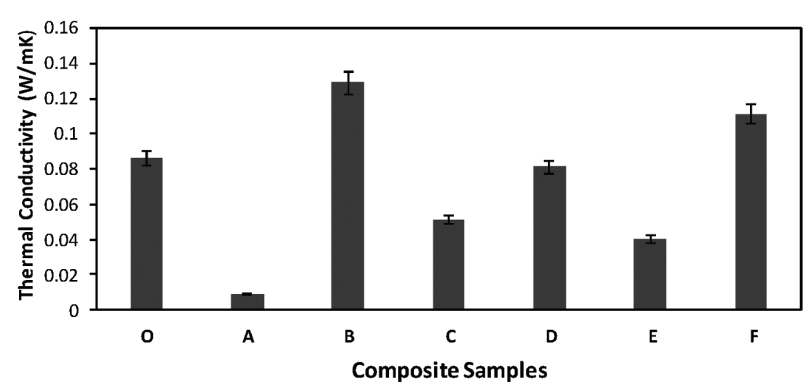

Figure 10: Variation of the thermal conductivity with the composite samples 


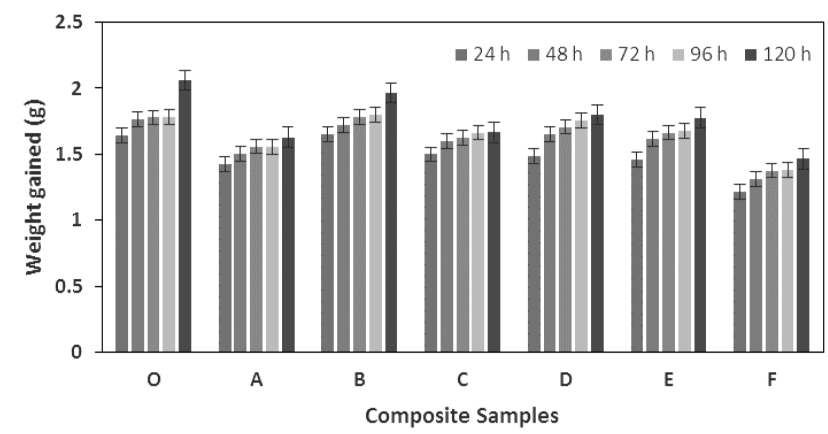

Figure 11: Plot showing the variation in the weight gained for the composites samples

to be a high rate of heat conduction due to high level of dispersion of the individual fibers within the paper pulp/cement matrix. This trend was in agreement with the work of, ${ }^{22}$ which reported that the thermal conductivity of composites was found to have increased with an increase in the volume fraction of thermally conductive filler. However, composite samples with $5 / 15 w / \%$ and $15 / 5 w / \%$ JB fibers showed minimum results for the thermal conductivity with a respective value of $0.051 \mathrm{~W} / \mathrm{mK}$ and $0.040 \mathrm{~W} / \mathrm{mK}$. This reduction in the thermal conductivity can be attributed to the presence of combined JB fibers in the composite samples. This implies that the best thermal conductivity can be achieved mainly in composite samples with an individual fiber addition.

The representative variation in weight gained is as displayed in Figure 11. It was observed that the water absorption with the composites increases with immersion time, although the rate of absorption decreases with increased time. It is also noticed that the water absorption attains equilibrium after $120 \mathrm{~h}$. At this stage, the composites were observed to have attained the saturation point as far as water absorption is concerned. However, it was noted from Figure 12 that the amount of water absorbed by the composite samples showed a sinusoidal wave pattern, i.e., increases/decreases as the fiber content in the composites changes. The percentage water absorption for the control and sample A, which has no fiber addition as shown in Figure 12, are $1.806 \%$ and $1.533 \%$, respectively. It is evident from the results that

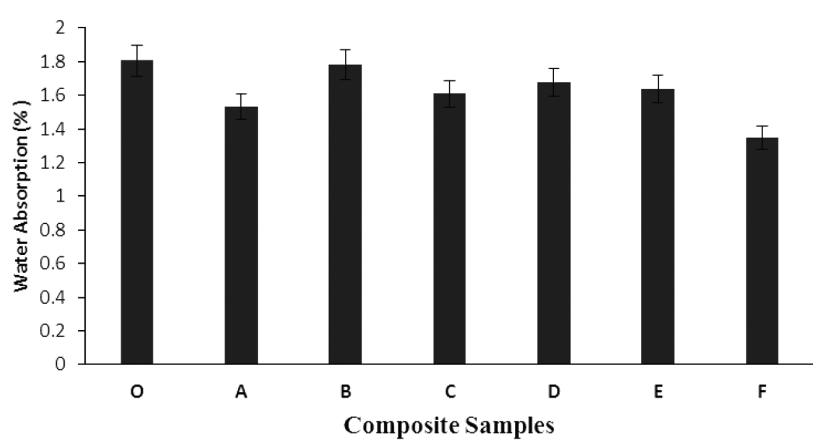

Figure 12: Percentage of water absorption of the composite samples less absorption took place in composite sample $\mathrm{F}$ with $0 / 20 w / \%$ jute/banana fiber content with an average value of $1.348 \%$, followed by composite sample C with $15 / 5 w / \%$ JB fibers content with a value of $1.609 \%$. This showed that composite samples with individual fiber content (in this case banana fiber) absorbed less water when compared with composite samples having both fiber contents. Authors ${ }^{23}$ reported that the water-absorption property of polymer matrix composites reinforced with natural fiber, particulate and their derivatives, is dependent on the amount of the fiber/particulate, the fiber orientation or the degree of particles dispersion, immersion temperature, and the area of the exposed surface to water. The morphology of the developed composites was examined using a scanning electron microscope (SEM) and the results revealed that composite samples without any fiber addition. Figure 13a has a noticeable level of fine and coarse aggregate of paper pulp/cement matrix as well as microcavities, which cannot be seen in the composite sample with jute/banana fiber addition Figure 13b. This shows that the fiber addition was able to fill the cavities, which were not seen in the FCB sample D in Figure 13b, as reported by ${ }^{24,25}$ the mechanical treatment given to the fibres was also responsible for the good interfacial bonding formed at the fibre/matrix and/or fiber/fiber interface as observed in Figure 13b. Furthermore, the good interfacial bonding between the fibres and the matrix also contributed to the improved mechanical properties observed in the composite sample D, as reported previously in this research.
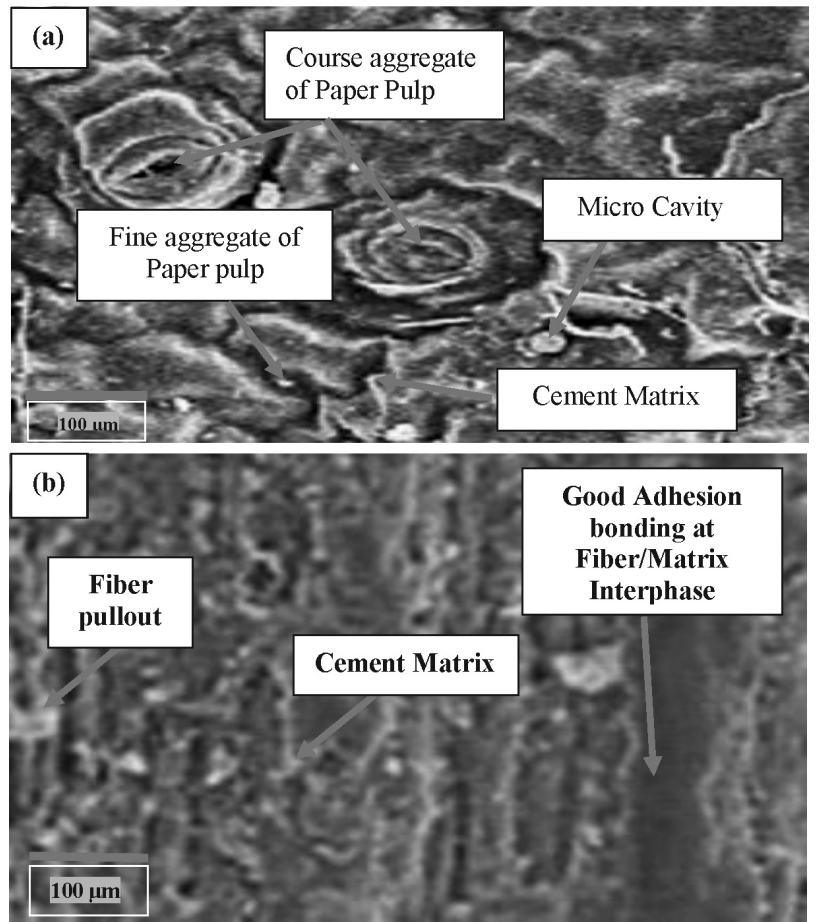

Figure 13: a) SEM image for sample A, b) SEM image for sample D 


\section{CONCLUSIONS}

Based on the current studies involving the use of selected naturally occurring fiber such as jute and banana fiber to serve as reinforcing material in paper pulp/cement-based composites. The following conclusions were drawn:

a) FCB sample D with $10 w / \%$ jute and $10 w / \%$ banana fiber content has the best flexural strength with a value of $0.84343 \mathrm{MPa}$, followed by $20 w / \%$ jute with a value of $0.77946 \mathrm{MPa}$. Although the incorporation of both fiber contents causes an enhancement in the flexural strength at yield of all the composites developed, but it was discovered that the jute fiber was more responsible for the improved strength when the FCB samples B and $\mathrm{F}$ with individual fiber content were compared.

b) The amount of water absorbed by the composites increases with the increase in the fiber content. This is due to the agglomeration of the fibers within the composite at higher fiber loading, which led to cracks and the formation of cavities at the fiber-matrix interphase, which allow the transmission of water into the composite at higher fiber loadings.

c) A fiber cement board composite sample D with $10 \mathrm{w} / \%$ jute, and $10 \mathrm{w} / \%$ banana fiber in combination with $15 \mathrm{w} / \%$ cement/bagasse and $65 \mathrm{w} / \%$ paper pulp can be used to develop a composite material which may serve as a close substitute for asbestos in housing construction in Nigeria.

\section{Acknowledgment}

The authors appreciate Landmark University Centre for Research, Innovation and Development (LUCRID) through SDGs-9 (Industry, Innovation and Infrastructure) for their support.

\section{REFERENCES}

${ }^{1}$ Z. Ortega, M. Morón, M. D. Monzón, P. Badalló, R. Paz, Production of Banana Fiber Yarns for Technical Textile Reinforced Composites, Journal of Materials, 9 (2016), 1-16

${ }^{2}$ I. O. Oladele, A. M. Okoro, J. A. Omotoyinbo, M. C. Khoathane, Evaluation of the Mechanical Properties of Chemically Modified Chicken Feather Fibres Reinforced High Density Polyethylene Composites, Journal of Taibah University for Science, 12, (2018b) 1, $56-63$

${ }^{3}$ I. O. Oladele, I. O. Ibrahim, A. A. Adediran, A. D. Akinwekomi, Y. V. Adetula, T. M. A. Olayanju, Modified palm kernel shell fiber/particulate cassava peel hybrid reinforced epoxy composites, Results in Materials, 5 (2020), 100053

${ }^{4}$ H. S. Sobral, Proceedings of the $2^{\text {nd }}$ International Symposium on Vegetable Plants and Building Materials, Salvadon, Brazil, RILEM Proceedings, 7 (2014)

${ }^{5}$ A. Ticoalu, T. Aravinthan, F. Cardona, A review of current development in natural fiber composites for structural and infrastructure applications, Proceedings of the Southern Region Engineering Conference (SREC '10), (2010) 113-117, Toowoomba, Australia

${ }^{6}$ I. O. Oladele, A. I. Baraka, A. S. Taiwo, I. O. Ibrahim, A. M. Masud, Development of natural polymer reinforced cement/waste paper pulp composites for structural application, Leonardo Electronic Journal of Practices and Technologies, 33 (2018), 1-14
${ }^{7}$ A. A. Adediran, O. A. Balogun, A. A. Akinwande, O. S. Adesina, O. S. Olasoju, Influence of chemical treatment on the properties of cement-paper hybrid composites for ceiling board application, Heliyon, 6 (2020) 7, e04512

${ }^{8}$ I. O. Oladele, I. S. Afolabi, A. S., Taiwo, Development of organic material based composites for packaging application using recycled papers, Leonardo Electronic Journal of Practices and Technologies, 30 (2017), 243-254

${ }^{9}$ M. Kumar, D. Kumar, Comparative Study of Pulping Banana Stem. Int. J. Fibre Text. Res. 1, (2011) 1-5

${ }^{10}$ P. Gañan, R. Zuluaga, J. M. Velez, I. Mondragon, Biological Natural Retting for Determining the Hierarchical Structuration of Banana Fibers, Macromol. Biosci., 4 (2004) 978-983

${ }^{11}$ N. Jacob, P. Prema, Novel Process for the Simultaneous Extraction and Degumming of Banana Fibers Under Solid-state Cultivation Braz. J. Microbiol., 39 (2008) 115-121

${ }^{12}$ T. Kinnarinen, A. Häkkinen, Influence of Enzyme Loading on Enzymatic Hydrolysis of Cardboard Waste and Size Distribution of the Resulting Fiber Residue Bioresour. Technol., 159 (2014) 136-142

${ }^{13}$ N. Jacob, K. N. Niladevi, G. S. Anisha, P. Prema, Hydrolisis of Pectin: An Enzymatic Approach and its Applications in Banana Fiber Processing. Microbiol. Res. 163, (2008) 538-544

${ }^{14}$ H. Tibolla, F. M. Pelissari, F. C. Menegalli, Cellulose Nanofibers Produced from Banana Peel by Chemical and Enzymatic Treatment. LWT Food Sci. Technol., 59 (2014) 1311-1318

${ }^{15}$ I. O. Oladele, A. D. Akinwekomi, S. Aribo, A. K. Aladenika, Development of Fibre Reinforced Cementitious Composite for Ceiling Application, Journal of Minerals and Materials Characterisation and Engineering, 8 (2009) 8, 583-590

${ }^{16}$ O. I. Oluwole, T. A. Samuel, A. A. Adediran, O. A. Mathew, A. O. Emmanuel; Design and Fabrication of Waste Paper Recycling Machine for Laboratory and Medium Scale Operation, Journal of Production Engineering, 22 (2019) 1, 19-24

${ }^{17}$ ASTM D303-08 Standard Test Method for Compressive Strength of Concrete Cylinders Cast in Place in Cylindrical Moulds, West Conshohocken, PA

${ }^{18}$ ASTM D7264M-07 Standard Test Method for Flexural Strength of Composite Materials, West Conshohocken, PA.

${ }^{19}$ I. O. Oladele, M. O. Oladejo, A. A. Adediran, B. A. Makinde-Isola, A. F. Owa, E. T. Akinlabi, Influence of designated properties on the characteristics of dombeya buettneri fiber/graphite hybrid reinforced polypropylene composites, Scientific Reports, 10 (2020), 11105

${ }^{20}$ ASTM D570-10, Standard Test Method for Water Absorption of Plastics, ASTM International, West Conshohocken, PA, (2010)

${ }^{21}$ H. Frank, W. Bernd, Reinforcement of Thermosetting Polymers by the Incorporation of Micro- and Nanoparticles Institute for Materials Ltd., Kaiserslautern University of Technology, Kaiserslautern, Germany (2005)

${ }^{22}$ O. O. Daramola, O. S. Akintayo, T. A. Adewole, H. K. Talabi, Mechanical Properties and Water Absorption Behaviour of Polyester/Soil-Retted Banana Fiber (SBRF) Composites, International Journal of Engineering, Annals of Faculty of Engineering Hunedoara, Tome XV, Fascicule 1, (2017) 183-190

${ }^{23}$ H. N., Dhakal, Z. Y. Zhang, M. O. W. Richardson, Effect of Water Absorption on the Mechanical Properties of Hemp Fiber Reinforced Unsaturated Polyester Composites, Journal of Composite Science and Technology, 67 (2007) 7, 1674-1683

${ }^{24}$ I. O. Oladele, J. A. Omotoyinbo, J. O. T. Adewara, Investigating the Effect of Chemical Treatments on the Constituents and Tensile Properties of Sisal Fibers, Journal of Minerals and Materials Characterization and Engineering, 9 (2010) 6, 569-568

${ }^{25}$ A. E. Faola, I. O. Oladele, B. O. Adewuyi, K. E. Oluwabunmi, Effect of Chemical Treatment on Water Absorption Capability of Polyester Composite Reinforced with Particulate Agro-Fibres. International Institute for Science, Technology and Education (IISTE), Chemistry and Materials Research, 3 (2013) 13, 106-112 